\title{
Diagnostic accuracy of symptoms as a diagnostic tool for SARS-CoV 2 infection: a cross-sectional study in a cohort of 2,173 patients
}

Carlos Alfonso Romero-Gameros ${ }^{1 \dagger}$, Tania Colin-Martínez ${ }^{2 \dagger}$, Salomón Waizel-Haiat ${ }^{1 \dagger}$, Guadalupe Vargas-Ortega ${ }^{3}$, Eduardo Ferat-Osorio ${ }^{4}$, José Alberto Guerrero-Paz', Marielle Intriago-Alor', Mayra Alejandra López-Moreno ${ }^{1}$, Carlos Fredy Cuevas-García ${ }^{5}$ Victoria Mendoza-Zubieta ${ }^{4}$, Jose Luis Martínez-Ordaz ${ }^{4}$ and Baldomero González-Virla ${ }^{3^{*}}$

\begin{abstract}
Background: The SARS-CoV-2 pandemic continues to be a priority health problem; According to the World Health Organization data from October 13, 2020, 37,704,153 confirmed COVID-19 cases have been reported, including 1, 079,029 deaths, since the outbreak. The identification of potential symptoms has been reported to be a useful tool for clinical decision-making in emergency departments to avoid overload and improve the quality of care. The aim of this study was to evaluate the performances of symptoms as a diagnostic tool for SARS -CoV-2 infection.

Methods: An observational, cross-sectional, prospective and analytical study was carried out, during the period of time from April 14 to July 21, 2020. Data (demographic variables, medical history, respiratory and non-respiratory symptoms) were collected by emergency physicians. The diagnosis of COVID-19 was made using SARS-CoV-2 RTPCR. The diagnostic accuracy of these characteristics for COVID-19 was evaluated by calculating the positive and negative likelihood ratios. A Mantel-Haenszel and multivariate logistic regression analysis was performed to assess the association of symptoms with COVID-19.

Results: A prevalence of $53.72 \%$ of SARS-CoV-2 infection was observed. The symptom with the highest sensitivity was cough $71 \%$, and a specificity of $52.68 \%$. The symptomatological scale, constructed from 6 symptoms, obtained a sensitivity of $83.45 \%$ and a specificity of $32.86 \%$, taking $\geq 2$ symptoms as a cut-off point. The symptoms with the greatest association with SARS-CoV-2 were: anosmia odds ratio (OR) 3.2 (95\% Cl; 2.52-4.17), fever OR 2.98 (95\% Cl; 2.47-3.58), dyspnea OR 2.9 (95\% Cl; 2.39-3.51]) and cough OR 2.73 (95\% Cl: 2.27-3.28).
\end{abstract}

Conclusion: The combination of $\geq 2$ symptoms / signs (fever, cough, anosmia, dyspnea and oxygen saturation < 93\%, and headache) results in a highly sensitivity model for a quick and accurate diagnosis of COVID-19, and should (Continued on next page)

\footnotetext{
* Correspondence: baldogonzal@hotmail.com

${ }^{\dagger}$ Carlos Alfonso Romero Gameros, Tania Colin-Martínez and Salomón Waizel-

Haiat contributed equally to this work.

${ }^{3}$ Endocrinology Service, Hospital de Especialidades, Centro Médico Nacional

Siglo XXI, Instituto Mexicano del Seguro Social, 330 Cuauhtémoc Avenue,

06720 Mexico City, Mexico

Full list of author information is available at the end of the article
}

(C) The Author(s). 2021 Open Access This article is licensed under a Creative Commons Attribution 4.0 International License, which permits use, sharing, adaptation, distribution and reproduction in any medium or format, as long as you give appropriate credit to the original author(s) and the source, provide a link to the Creative Commons licence, and indicate if changes were made. The images or other third party material in this article are included in the article's Creative Commons licence, unless indicated otherwise in a credit line to the material. If material is not included in the article's Creative Commons licence and your intended use is not permitted by statutory regulation or exceeds the permitted use, you will need to obtain permission directly from the copyright holder. To view a copy of this licence, visit http://creativecommons.org/licenses/by/4.0/. The Creative Commons Public Domain Dedication waiver (http://creativecommons.org/publicdomain/zero/1.0/) applies to the data made available in this article, unless otherwise stated in a credit line to the data. 
(Continued from previous page)

be used in the absence of ancillary diagnostic studies. Symptomatology, alone and in combination, may be an appropriate strategy to use in the emergency department to guide the behaviors to respond to the disease.

Trial registration: Institutional registration R-2020-3601-145, Federal Commission for the Protection against Sanitary Risks 17 Cl-09-015-034, National Bioethics Commission: 09 CEl-023-2017082.

Keywords: COVID-19, Diagnostic accuracy, SARS-CoV-2, Positive predictive value, Symptomatology

\section{Background}

The SARS-CoV-2 pandemic continues to be a priority health problem. According to figures of the WHO, as of October 13, 2020; 37,704,153 confirmed cases have been reported, including 1,079,029 deaths, since the outbreak. The majority were concentrated in the region of the Americas, representing $48 \%$ of cases and 55\% of total deaths [1]. In Mexico, since the first case was confirmed, to November 1, 2020; a total of 929,392 cases and 91, 895 deaths have been reported [2].

It have been determined that the peak of infectiousness occurs in the early stages, so timely interventions plays an important role in controlling its spread [3, 4]. Currently, diagnostic tools for SARS-CoV-2 infection, include methods based on viral nucleic acid detection, antigen-antibody reaction tests and imaging studies such as chest computed tomography $[5,6]$. However, in low income countries, where human and material resources are limited, the use of algorithms based on clinical data has been suggested to help correctly identify patients with a high probability for COVID-19 and thus achieve the resource optimization [7]. Symptom evaluation have been reported to be a useful tool for clinical decision-making in emergency departments, to avoid work overload and to improve the quality of care $[8,9]$.

In July of this year and with the aim of assessing the diagnostic accuracy of signs and symptoms, Struyf et al. conducted a systematic review of 16 studies (including 7706 patients). The authors concluded that the evaluation of signs and symptoms (individually) has little value for the diagnosis of SARS-CoV-2, and thus emphasized the urgent need of prospective clinical studies which evaluate the combination of signs and symptoms, in search of greater specificity for the detection of the SARS-CoV-2 infection [10].

The aim of the study was to evaluate and establish the diagnostic performance of the symptoms and signs (isolated and in combination) in patients with suspected COVID-19, as a screening tool for the correct identification of positive cases.

\section{Material and methods}

An observational, transversal, prospective and analytical study was carried out at the Hospital de
Especialidades del Centro Médico Nacional Siglo XXI of the Social Security Mexican Institute IMSS (a tertiary care center), in Mexico City, Mexico; during the period from April 14 to July 21, 2020, with patients who arrived at the emergency area due to COVID-19 suspicion.

This study was approved by the National Commission on Bioethics (09 CEI-023-2,017,082), the Federal Commission for Protection against Health Risks Research (17 CI-09-015-034) and the local hospital research committee (R-2020-3601-145).

\section{Data collection}

The study included patients who came to the emergency department for medical attention due to suspected COVID-19. Patients were selected through a nonprobabilistic sampling of consecutive cases according to the order of arrival at the emergency department. The patients were evaluated and selected by 6 emergency physicians who, according to the guidelines established by the Mexican General Directorate of Epidemiology [11], indicated the collection of a sample for detection of SARS-CoV-2 by RT-PCR.

The data were collected through the application of a questionnaire consisting of 30 variables, applied by six emergency physicians during the assessment in the emergency area, in which demographic variables (age, gender) were included; as well as their medical history (comorbidities, vital signs, anthropometry), respiratory and non-respiratory symptoms related to the SARS-CoV-2 infection (fever, cough, odynophagia, chest pain, asthenia, myalgia, rhinorrhea, headache, anosmia, conjunctivitis, and dyspnea). Fever was defined as the presence of a body temperature greater than $38^{\circ} \mathrm{C}\left(100.4^{\circ} \mathrm{F}\right)$.

The patients had to meet the following inclusion criteria in order to be able to participate: patients over 17 years of age of both genders, who signed an informed consent form, patients with a high clinical probability of SARS-CoV-2 infection; and who had confirmatory SARS-CoV-2 RT-PCR.

Patients who did not have a SARS-CoV-2 RT-PCR result and who did not sign an informed consent form were excluded Fig. 1. 


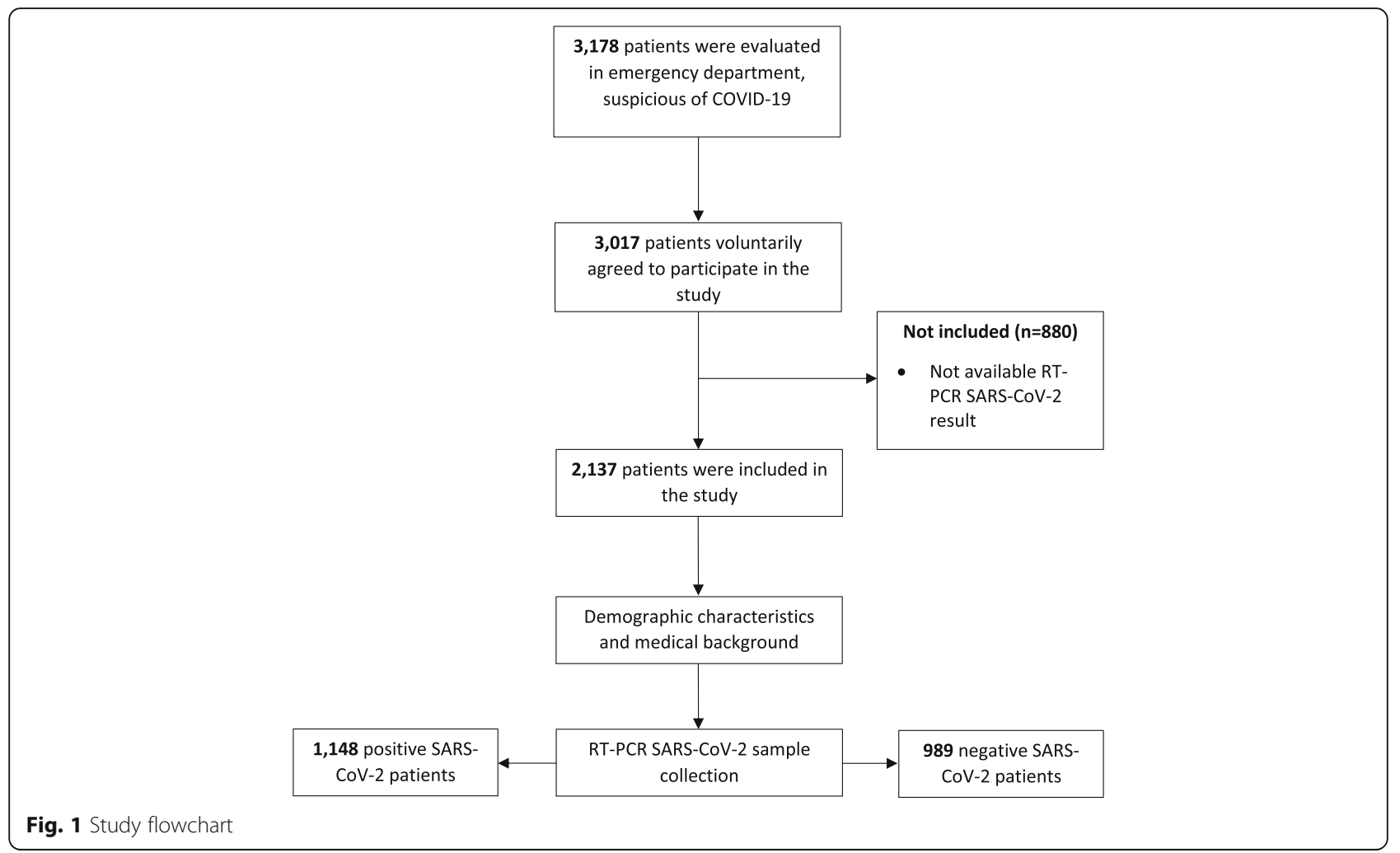

\section{Diagnosis of SARS-CoV-2}

The decision to test for SARS-CoV-2 was made according to the clinical judgment of the emergency physician in charge. The identification of SARS-CoV-2 was performed by real time RT-PCR, in samples of nasopharyngeal exudate which were sent to the Central Laboratory of Epidemiology of the National Medical Center " $L a$ $R a z a$ " for their processing, following the international standards for the transport of infectious substances. The sample processing for the detection of SARS-CoV-2 was performed according to the guidelines certified by the National Institute for Diagnosis and Epidemiological Referral [12].

\section{Construction of the symptom diagnostic scale}

A combination of the symptomatology related to the SARS-CoV-2 infection was assessed to calculate the association and magnitude of it with the presence of COVID-19, to construct the diagnostic scale. Symptom selection was made according to a model obtained through a LASSO regression.

\section{Statistical analysis}

Descriptive and inferential statistics were used for the data analysis, taking into account measures of central tendency and dispersion. For the comparison of frequencies and proportions, a chi-square statistical test was used. To compare the quantitative variables, we used the Mann-Whitney's U statistical test, or $\mathrm{T}$ test according to the distribution of the variables. The Kolmogorov-Smirnov test was used to determine the normality in the variable's distribution.

A stratified Mantel-Haenszel analysis was performed to assess the association of symptoms to the probability of a SARS-CoV-2 positive result. For each symptom, sensitivity and specificity, positive likelihood ratio (LR+), negative likelihood ratio (LR-), accuracy, and area under the curve (AUC) were calculated, as a diagnostic tool for identifying the SARS-CoV 2 infection. A multiple logistic regression analysis was performed, including symptoms -alone and in combination- related to SARS-CoV-2 infection, adjusted for age, gender, and comorbidities, to estimate the magnitude of the association. A LASSO regression analysis was used to establish the symptomatology of a SARS-CoV2 infection. A value of $P<0.05$ was considered statistically significant. The statistical program used was SPSS, version 25.0 (IBM SPSS Statistics for Windows. Armonk, NY: IBM Corp) and the Stata SE software, version 16 (StataCorp, TX, USA).

\section{Results}

Baseline characteristics of patients with SARS-CoV-2 infection

During the study period, a total of 3178 patients were evaluated in the emergency area for suspected COVID19. 3017 patients voluntarily agreed to participate in the 
study; 880 patients did not have a SARS-CoV-2 RT-PCR test, because they didn't meet the definition of a suspected case, according to the guidelines of the Mexican General Directorate of Epidemiology [11], so they were not included. At the end, a total of 2137 patients were included; 1148 (53.72\%) were positive for SARS-CoV-2; of the SARS-CoV-2 positive group, $508(44.25 \%, P<$ 0.001 ) were female, with an average age of 48.60 ( $\mathrm{SD} \pm$ 15.6, $P<0.001$ ) Table 1.

The following vital signs were obtained at the time of evaluation in the emergency room: heart rate of 94 beats per minute (IQR; $82-108, P<0.001$ ), respiratory rate of 22 breaths per minute (IQR; $20-24, P<0.001$ ), and pulse oximetry oxygen saturation of less than 93\% (SO2<93\%) (IQR; 85-95, $P<0.001$ ), mean systolic blood pressure of $131 \mathrm{mmHg}(\mathrm{SD} \pm 18.67, P=$ 0.78 ), and diastolic blood pressure of $76 \mathrm{mmHg}$ ( $\mathrm{SD} \pm$ 24.42, $P=0.82)$ Table 1.

\section{Symptoms associated with SARS-CoV-2 infection}

In the patients assessed, the most frequent symptom was cough in $71.08 \%(P<0.001)$, followed by asthenia in 68.73\% $(P<0.001)$, headache in $67.76 \%(P=0.11)$, myalgia in $61.4 \%(P<0.001)$, fever in $53.57 \%(P<0.001)$, odynophagia in $50 \%(P=0.62)$, dyspnea in $47.91 \%(P<$ $0.001)$, chest pain in $38.76 \%(P<0.001)$, rhinorrhea in $32.49(P=0.03)$ and anosmia in $26.92 \%(P<0.001)$; the least frequent being conjunctivitis, in $14.11 \%(P=0.87)$ Table 1.

\section{Comorbidities in the SARS-CoV-2 positive patient group}

The most frequent comorbidity was obesity $(60.47 \%, P<$ $0.001)$, followed by hypertension $(24.38 \%, P<0.001)$, type 2 diabetes mellitus $(18.99 \%, P<0.001)$ and chronic renal disease $(4.78 \%, P=0.04)$ Table 1 .

\section{Stratified and multivariate analysis of the} symptomatology of SARS-CoV-2 positive patients Anosmia presented an odds ratio (OR) of 3.2 ([95\% CI: 2.52-4.17], $P<0.001$ ), followed by fever with an OR of 2.98 ([95\% CI: $2.47-3.58], P<0.001$ ), dyspnea with OR of 2.9 ([95\% CI: $2.39-3.51], P<0.001$ ), cough with OR of 2.73 ([95\% CI: 2.27-3.28], $P<0.001$ ) and oxygen saturation $<93 \%$ OR of 2.73 ([95\% CI: 1.89-4], $P<0.001$ ) Table 2 and Fig. 2.

An OR of 12.13 ([95\% CI: 1.6-92.92], P < 0.001) was obtained for the combination of fever, cough, anosmia, dyspnea, and oxygen saturation of less than $93 \%$ ( $\mathrm{SO} 2<$ 93\%); similarly, for the cough-fever combination, with an OR of 4. 44 ([95\% CI: 3.61-5.47], $P<0.001$ ), and for fever-anosmia, with an OR of 4.3 ([95\% CI: 3.05-6.07], $P<0.001)$. Table 2 and Image 2.

In a multivariate logistic regression model where isolated and combined symptoms were included, adjusted for age, gender and comorbidities; anosmia had an OR of 2.96 ([95\% CI: 2.27-3.87], $P<0.001$ ), followed by the combination of cough-fever with an OR 2.79 ([95\% CI: 2.12-3.69], $P<0.001)$ and cough-anosmia with an OR of 2.48 ([95\% CI: 1.65-3.74], $P<0.001$ ) Table 2.

\section{Diagnostic performance of the symptomatology, as a tool for SARS-CoV-2 identification}

The three combinations of symptoms with more specificity were: fever-cough-anosmia-dyspnea-SO2 $<93 \%$, fever-anosmia and anosmia-dyspnea. The symptoms with greater sensitivity were cough, asthenia, and headache. See Table 3.

\section{Performance of the symptoms scale as a diagnostic instrument for SARS-CoV-2}

Table 4 shows the sensitivity, specificity, LR+, LR-, accuracy test and AUC of the symptomatology scale in which the following symptoms (according to the predictability of the independent variables through LASSO regression) were included: fever, cough, anosmia, dyspnea, $\mathrm{SO} 2<93 \%$ and headache. The highest sensitivity was obtained with the presence of two or more symptoms, $83.45 \%$ ([95\% CI: 81.17-85.55\%], $P<0.001$ ), specificity of $32.86 \%$ ([95\% CI: $29.94-35.89 \%], P<0.001$ ).

\section{Stratified and multivariate analysis of the symptoms scale} for the diagnosis of SARS-CoV-2 with positive patients

The stratified analysis found an OR of the combination of $\geq 4$ symptoms of 3.97 ([95\% CI: 3.25-4.84], $P<0.001$ ); and of the combination of $\geq 5$ symptoms of 5.34 ([95\% CI: 4.02-7.17], $P<0.001)$. With the adjustment of the symptomatology scale by age and gender, the OR obtained was, for $\geq 4$ symptoms and for $\geq 5$ symptoms, of 2.01 ([95\% CI: 1.15-2.69], $P<0.001$ ) and of 2.16 ([95\% CI: 1.45-3.20], $P<0.001)$, respectively Table 5 .

\section{Discussion}

The purpose of this study was to evaluate the diagnostic performance of the symptomatology in detecting the SARS-CoV-2 infection. Recently, we reported the diagnostic accuracy of smell disorders, detected by psychophysical tests and by the application of a self-perception questionnaire, in the Mexican population (sensitivity of $19.44 \%$ and specificity $95.52 \%[P=0.007]$; sensitivity of $50 \%$ and specificity $80.59 \%[P<0.001]$, respectively) [13]. However, so far there are no studies done within the Mexican population to evaluate the above-mentioned objective.

In Mexico, some social conditions have been observed that cause a greater severity of COVID-19, such as: belonging to an indigenous population, a low socioeconomic level or living in the southern states of the country [14]. The lack of universal 
Table 1 Baseline characteristics and clinical history of 2137 patients presenting for COVID-19 suspicion

\begin{tabular}{|c|c|c|c|c|}
\hline Variable & Total $(n=2137)$ & $\begin{array}{l}\text { Positive SARS CoV2 patients } \\
(n=1148)\end{array}$ & $\begin{array}{l}\text { Negative SARS CoV2 patients } \\
(n=989)\end{array}$ & $P$ Value \\
\hline Age, mean $\pm S D$ & $45.93 \pm 15.34$ & $48.60 \pm 15.6$ & $42.82 \pm 14.42$ & $<0.001^{a}$ \\
\hline \multicolumn{5}{|l|}{ Gender, n (\%) } \\
\hline Female & $1034(48.3)$ & $508(44.2)$ & $526(53.1)$ & \multirow[t]{2}{*}{$<0.001^{b}$} \\
\hline Male & $1103(51.6)$ & $640(55.7)$ & $463(46.8)$ & \\
\hline \multicolumn{5}{|l|}{ Vital sings } \\
\hline Temperature $\left(\mathrm{C}^{\circ}\right)$, median (IQR) & $36.4(36.2)$ & $36.4(36.2-36.8)$ & $36.4(36.2-36.7)$ & $0.01^{c}$ \\
\hline Hear rate (bpm), median (IQR) & $90(78-103)$ & $94(82-108)$ & $87(75-99)$ & $<0.001^{c}$ \\
\hline Respiratory rate (bpm), median (IQR) & $22(20-24)$ & $22(20-24)$ & $22(20-24)$ & $<0.001^{c}$ \\
\hline $\mathrm{SBP}(\mathrm{mmHg})$, mean $\pm \mathrm{SD}$ & $191.2 \pm 19.1$ & $131.3 \pm 18.6$ & $131.1 \pm 19.7$ & $0.78^{\mathrm{a}}$ \\
\hline $\mathrm{DBP}(\mathrm{mmHg})$, mean $\pm \mathrm{SD}$ & $76.6 \pm 20.0$ & $76.7 \pm 24.4$ & $76.5 \pm 13.2$ & $0.82^{\mathrm{a}}$ \\
\hline Oxygen saturation (\%), median (IQR) & $94(90-95)$ & $93(85-95)$ & $95(93-96)$ & $<0.001^{c}$ \\
\hline Weight (kg), median (IQR) & $74(63-85)$ & $75(64-86)$ & $72(62-84)$ & $<0.001^{c}$ \\
\hline Height $(m)$, mean $\pm S D$ & $1.63 \pm 0.09$ & $1.62 \pm 0.09$ & $1.63 \pm 0.09$ & $0.42^{\mathrm{a}}$ \\
\hline $\mathrm{BMI}\left(\mathrm{kg} / \mathrm{m}^{2}\right)$, median (IQR) & $27.8(24.76-31.21)$ & $28.4(25.28-31.74)$ & $27.3(24.11-30.46)$ & $<0.001^{c}$ \\
\hline Oxygen saturation < 93\%, n (\%) & $170(7.96)$ & $127(11.06)$ & $43(4.35)$ & $<0.001^{a}$ \\
\hline \multicolumn{5}{|l|}{ General symptoms, $\mathrm{n}(\%)$} \\
\hline Fever & $891(41.69)$ & $615(53.57)$ & $276(27.91)$ & $<0.001^{b}$ \\
\hline Cough & $1284(60.08)$ & 816 (71.08) & $468(47.32)$ & $<0.001^{b}$ \\
\hline Odynophagia & $1058(49.51)$ & $574(50.00)$ & $484(48.94)$ & $0.62^{b}$ \\
\hline Thoracic pain & 708 (33.13) & $445(38.76)$ & $263(26.59)$ & $<0.001^{b}$ \\
\hline Asthenia & $1354(63.36)$ & 789 (68.73) & $565(57.13)$ & $<0.001^{b}$ \\
\hline Myalgia & $1188(55.59)$ & $705(61.41)$ & $483(48.84)$ & $<0.001^{b}$ \\
\hline Rhinorrhea & $652(30.51)$ & $373(32.49)$ & $279(28.21)$ & $0.03^{b}$ \\
\hline Headache & $1287(60.22)$ & 709 (61.76) & $578(58.44)$ & $0.11^{b}$ \\
\hline Anosmia & $410(19.19)$ & 309 (26.92) & $101(10.21)$ & $<0.001^{b}$ \\
\hline Conjunctivitis & $304(14.23)$ & $162(14.11)$ & $142(14.36)$ & $0.87^{b}$ \\
\hline Dyspnea & $788(36.87)$ & $550(47.91)$ & $238(24.06)$ & $<0.001^{b}$ \\
\hline \multicolumn{5}{|l|}{ Comorbidities, n (\%) } \\
\hline COPD & $29(1.36)$ & $21(1.83)$ & $8(0.81)$ & $0.04^{b}$ \\
\hline Type 2 diabetes mellitus & $326(15.26)$ & $218(18.99)$ & $108(10.92)$ & $<0.001^{b}$ \\
\hline Hypertension & $447(20.92)$ & $285(24.83)$ & $162(16.38)$ & $<0.001^{b}$ \\
\hline Chronic Kidney disease & $84(3.93)$ & $54(4.78)$ & $30(3.03)$ & $0.04^{b}$ \\
\hline Immunodeficiency & $65(3.04)$ & $34(2.96)$ & $31(3.13)$ & $0.81^{b}$ \\
\hline Hepatopathy & $11(0.51)$ & $8(0.70)$ & $3(0.30)$ & $0.20^{b}$ \\
\hline Obesity & $1148(57.72)$ & $537(60.47)$ & $611(48.92)$ & $<0.001^{b}$ \\
\hline
\end{tabular}

Abbreviations: IQR interquartile range, SD standard deviation, $K g$ kilograms, $B M I$ body mass index, $m$ meters, COPD Chronic Obstructive Pulmonary Disease

a $P$ Value estimated with T test between SARS-CoV2 positive and SARS-CoV2 negative patients

b $P$ Value estimated with Pearson's $X^{2}$ test between SARS-CoV2 positive and SARS-CoV2 negative patients

${ }^{c} P$ Value estimated with U-Mann-Whitney between SARS-CoV2 positive and SARS-CoV2 negative patients

access to ancillary tests in the medical units, to quickly identify the probable cases of SARS-CoV-2, has led to the adoption of algorithms based on clinical data to help guide the decision-making process [7]. Correctly identifying patients with a high suspicion of infection by SARS-CoV-2 is paramount to the emergency services, for the control of infectious outbreaks $[15,16]$. Some authors have developed predictive models for the diagnosis of the SARSCoV-2 infection, to be used in settings where ancillary tests may not be available for first contact physicians [17-19]. However, the results of the studies 
Table 2 Stratified and multivariate analysis of symptomatology of 2137 patients presenting for COVID-19 suspicion

\begin{tabular}{|c|c|c|c|c|c|c|}
\hline \multirow[b]{2}{*}{ Variable } & \multicolumn{3}{|c|}{ Stratified analysis } & \multicolumn{3}{|c|}{ Multivariate analysis $^{\mathbf{b}}$} \\
\hline & $\overline{\mathrm{OR}}$ & $95 \% \mathrm{Cl}$ & $P$ vale $^{\mathrm{a}}$ & $\overline{\mathrm{OR}}$ & $95 \% \mathrm{Cl}$ & $P$ vale $^{a}$ \\
\hline Fever & 2.98 & $2.47-3.58$ & $<0.001$ & 1.96 & $1.58-2.41$ & $<0.001$ \\
\hline Cough & 2.73 & $2.27-3.28$ & $<0.001$ & 1.95 & $1.58-2.41$ & $<0.001$ \\
\hline Odynophagia & 1.04 & $0.87-1.24$ & 0.62 & & & \\
\hline Thoracic pain & 1.74 & $1.44-2.11$ & $<0.001$ & & & \\
\hline Asthenia & 1.64 & $1.37-1.97$ & $<0.001$ & & & \\
\hline Myalgia & 1.66 & $1.39-1.98$ & $<0.001$ & 1.25 & $1.00-1.56$ & 0.04 \\
\hline Headache & 1.14 & $0.96-1.37$ & 0.11 & & & \\
\hline Rhinorrhea & 1.22 & $1.01-1.48$ & 0.03 & & & \\
\hline Anosmia & 3.23 & $2.52-4.17$ & $<0.001$ & 2.96 & $2.27-3.87$ & $<0.001$ \\
\hline Conjunctivitis & 0.98 & $0.76-1.26$ & 0.87 & & & \\
\hline Dyspnea & 2.90 & $2.39-3.51$ & $<0.001$ & 1.48 & $1.17-1.87$ & 0.001 \\
\hline $\mathrm{O}_{2} \mathrm{~S}<93$ & 2.73 & $1.89-4.00$ & $<0.001$ & 1.56 & $1.17-1.87$ & 0.001 \\
\hline Fever and anosmia & 4.30 & $3.05-6.07$ & $<0.001$ & & & \\
\hline Cough and fever & 4.44 & $3.61-5.47$ & $<0.001$ & 2.79 & $2.12-3.69$ & $<0.001$ \\
\hline Cough and anosmia & 3.45 & $2.61-4.56$ & $<0.001$ & 2.48 & $1.65-3.74$ & $<0.001$ \\
\hline Fever and dyspnea & 3.72 & $2.96-4.67$ & $<0.001$ & & & \\
\hline Anosmia and dyspnea & 3.43 & $2.42-4.86$ & $<0.001$ & & & \\
\hline Fever, cough, anosmia, dyspnea, $\mathrm{O}_{2} \mathrm{~S}<93$ & 12.19 & $1.60-92.92$ & $<0.001$ & & & \\
\hline
\end{tabular}

Abbreviations: $\mathrm{OR}$ odds ratio, $\mathrm{O}_{2} \mathrm{~S}$ Oxygen saturation, $95 \% \mathrm{Cl}$ 95\% confidence interval

a $P$ Value estimated with Pearson's $X 2$ test

${ }^{\mathrm{b}}$ Multivariate logistic regression of symptomatology adjusted by age, gender and comorbidities

published as of today are inconclusive, partly because of their great heterogeneity [10].

Peyrony et al. [20] carried out a prospective observational study in a French hospital involving 391 patients, out of whom $225(57.66 \%)$ tested positive for SARSCoV-2 by RT-PCR. In this group, 53 (23.6\%) presented gastrointestinal symptoms such as vomiting, diarrhea, or abdominal pain; 147 (65.6\%) had a temperature below $38^{\circ} \mathrm{C}$ and $97(43.3 \%)$ below $37.5^{\circ} \mathrm{C}$ upon arrival at the emergency department. The symptomatic prevalence in the SARS-CoV-2 positive group was as follows: fever 176 (78.2\%), cough 158 (70.2\%), dyspnea 131 (58.2\%), myalgia $71(31.6 \%)$, rhinitis-pharyngitis $19(8.4 \%)$, anosmia 31 (13.8\%), headache 15 (6.7\%), fatigue 34 (15.1\%). Furthermore, the following symptoms were evaluated for their sensitivity and specificity: fever had a sensitivity of $78 \%$ and a specificity of $50 \%$; dyspnea had a sensitivity of $32 \%$ and a specificity of $87 \%$; anosmia had a sensitivity of $14 \%$ and a specificity of $98 \%$; and oxygen saturation below $95 \%$ had a sensitivity of $17 \%$ and a specificity of $91 \%$ for the SARS-CoV-2 diagnosis.

Tostmann et al. [18], studied 803 health-worker patients through a questionnaire to evaluate their symptoms associated to COVID-19; 112 patients were positive for SARS-CoV-2 infection, out of which 90 answered the instrument. The analytical model that included all variables (general non-respiratory, respiratory, and gastrointestinal symptoms) excluding fever and cough, reached an AUC of 0.75 (95\% CI:0.66-0.84), with a sensitivity of $82.4 \%$ and a specificity of $59.2 \%$. The second analytical model that included symptoms significantly associated with the SARS-CoV-2 infection (3 or more symptoms) such as anosmia, myalgia, asthenia, headache, eye pain, and malaise, yielded a sensitivity of $91.2 \%$ and specificity of $55.6 \%$ for SARS-CoV-2 positivity.

Salmon et al. [21], performed a prospective, multicenter observational study at 5 hospitals in Paris to determine the frequency of SARS-CoV-2 positive patients with a loss of sense of smell; and to analyze the diagnostic accuracy of olfactory and gustatory dysfunction for the diagnosis of COVID-19. A total of 1824 patients were included in the second phase of the study, out of whom 849 (46.5\%) tested positive for SARS-CoV-2. The positive predictive value (PPV) of olfactory and gustatory dysfunction was $78.5 \%$ (95\% CI: 76.6-80.3\%), with a sensitivity of $40.8 \%$ (95\% CI: $38.5-43.0 \%$ ), a specificity of 90.3\% (95\% CI: 88.9-91.6\%), and a negative predictive value (NPV) of $63.6 \%$ (95\% CI: 61.4-65.8\%). Cough obtained a sensitivity of $70.4 \%$ (95\% CI: $68.3-72.5 \%$ ), a specificity of $32.4 \%$ (95\% CI: $30.2-34.5 \%$ ), a PPV of $47.5 \%$ 


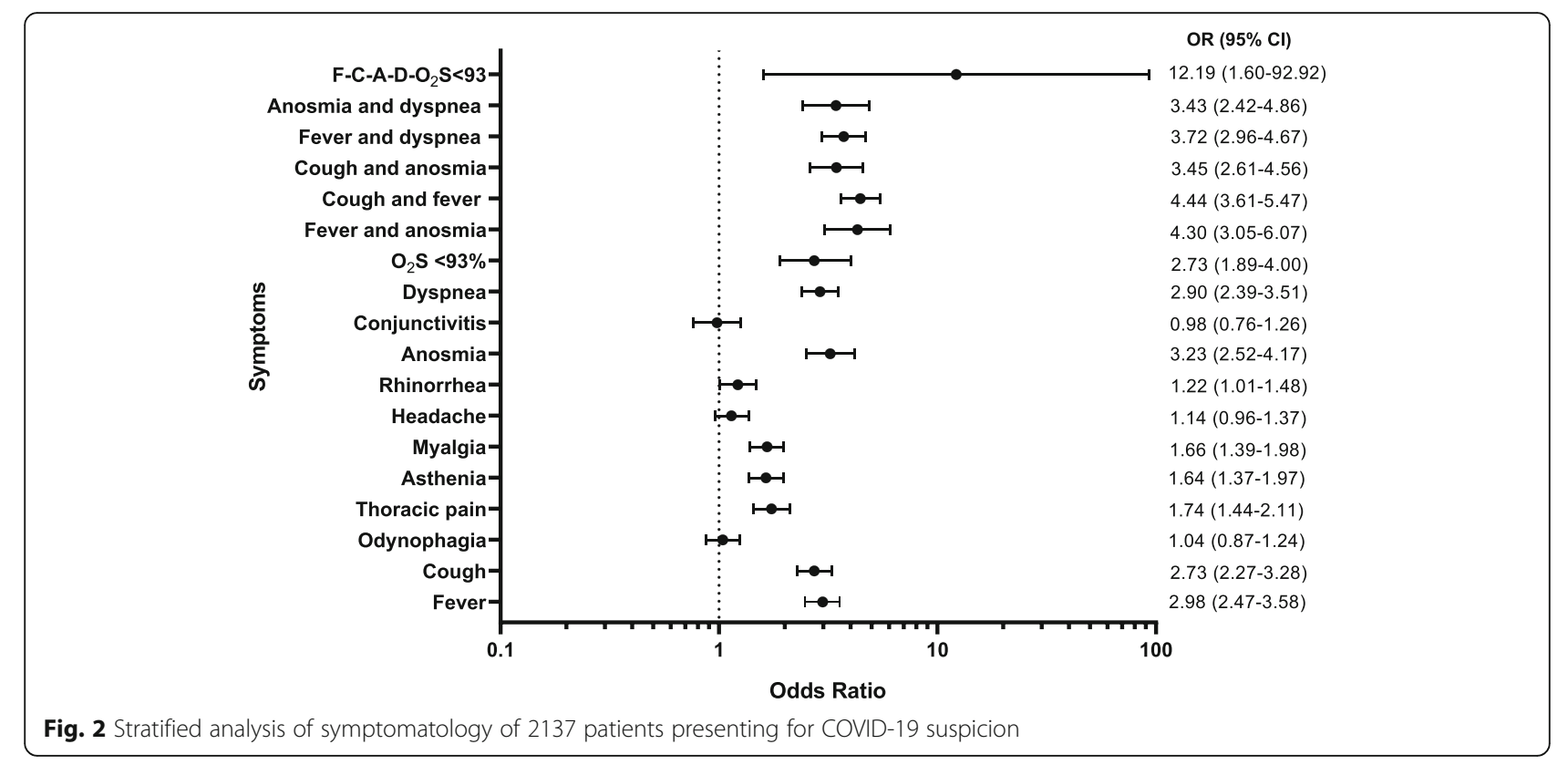

(95\% CI: $45.2-49.8 \%)$ and a NPV of $65.2 \%$ (95\% CI: 53.5-58.0\%).

In our series, we found a prevalence of SARS-CoV2 infection of $53.72 \%$. The most prevalent symptoms were: asthenia, headache and cough $(63.36,60.22 \%$ and $60.08 \%$ respectively), similar to those reported in other series $[18,21,22]$. The symptomatology that was significantly associated to the SARS-CoV-2 infection was the presence of anosmia, with an OR of 3.23 ([95\% CI: 2.52-4.17], $P<0.001$ ), fever OR of 2.98 ([95\% CI: 2.47-3.58], $P<0.001$ ), dyspnea OR of 2.9 ([95\% CI: $2.39-3.51], P<0.001$ ), cough OR of 2.73 ([95\% CI: $2.27-3.28], \quad P<0.001), \quad$ SO $2<93 \%$ OR of 2.73 ([95\% CI: 1.89-4.00], $P<0.001$ ) and myalgia with an OR of 1.66 ([95\% CI:1. 39-1.98], $P<0.001$ ); similar to what was reported by Lan et al. [22]. who found an OR of 6.5 (95\% CI: 2.89-14.51) for anosmia, fever OR of 3.34 (95\% CI: 2.07-5.41), myalgia OR of 2.41 (95\% CI:1.50-3.89). Similarly, Tostmann et al. [18] reported an OR for anosmia of 23 (95\% CI: 8.2-64.8), fever OR of 2.7 (95\% CI: 1.7-4.2) and myalgia OR of 6.9 (95\% CI: $4.2-11.3$ ). In a multivariate model where symptomatology was adjusted according to other predictive variables, an OR for fever of 1.96 (95\% CI: 1 . 58-2.41], $P<0.001)$, cough OR of 1.95 ([95\% CI: 1.58-2.41], $P<0.001$ ), anosmia OR of 2.96 ([95\% CI: 2.27-3.87], $P<0.001)$ and dyspnea OR of 1.48 ([95\% CI: 1.17-1.87], $P<0.001)$ were found.

Combining cough-fever and cough-anosmia resulted in an OR of 2.79 ([95\% CI: 2.12-3.69], $P<0.001$ ) and 2.48 ([95\% CI: $1.65-3.74, P<0.001$ ) respectively; something similar to what was reported by Lan et al. [22].
In our study, a symptomatology model was created where 6 symptoms were combined obtaining for $\geq 2$ symptoms, a sensitivity of $83.45 \%$ (95\% CI: $81.17-$ $85.55 \%$ ) and a specificity of $32.86 \%$ (95\% CI: $29.94-$ $35.89 \%)$; and an association with the presence of SARSCoV-2 with an OR of 2.46 ([95\% CI: 2.00-3.04, $P<$ 0.001). Similarly, Tostmann et al. reported a sensitivity of $91.2 \%$ and a specificity of $55.6 \%$, considering a cut-off point for 3 or more symptoms [18].

The findings of our study suggest that the symptomatology (anosmia, fever, dyspnea and cough) by itself have a close relationship with the presence of the SARSCoV-2 infection. Given the symptomatology complexity presented in this type of condition, the combination of symptoms, reported in different series, allows for a greater accuracy in the presumptive diagnosis of the SARS-CoV-2 infection (fever, cough, dyspnea, anosmia, $\mathrm{SO} 2<93 \%)$. Finally, the combination of symptoms significantly associated to SARS-CoV-2 infection, integrated in a predictive model, will allow for a faster and more accurate final diagnosis, when limited ancillary resources are available.

From the physio-pathological viewpoint, the presence of dyspnea and hypoxemia has its explanation in the lung damage caused by the virus. The high expression of ACE2 in the apical lung cells [23], promotes adhesion, penetration and destruction of lung tissue, causing a diffuse interstitial and alveolar inflammatory exudate production, as well as edema [24]. Regarding anosmia, some theories have emerged based on the findings of the neuro-invasion mechanism of SARS-CoV and MERS-CoV, due to the great 
Table 3 Diagnostic accuracy of symptoms as an instrument for detection of SARS-CoV-2 infection

\begin{tabular}{|c|c|c|c|c|c|c|c|c|c|}
\hline Symptoms & Sensitivity & Specificity & PPV \% & NPV \% & $\mathrm{LR}+$ & LR- & Accuracy & $P^{a}$ & AUC \\
\hline $\begin{array}{l}\text { Fever } \\
\%(95 \% \text { Cl) }\end{array}$ & $\begin{array}{l}53.57 \\
{[50.64-} \\
56.49]\end{array}$ & $\begin{array}{l}72.09 \\
{[69.18-} \\
74.87]\end{array}$ & $\begin{array}{l}69.02 \\
{[66.54-} \\
71.40]\end{array}$ & $\begin{array}{l}57.22 \\
{[55.42-} \\
59.01]\end{array}$ & $\begin{array}{l}1.92 \\
{[1.71-2.15]}\end{array}$ & $\begin{array}{l}0.64 \\
{[0.60-} \\
0.69]\end{array}$ & $\begin{array}{l}62.14 \\
{[60.05-} \\
64.21]\end{array}$ & $\begin{array}{l}< \\
0.001\end{array}$ & $\begin{array}{l}0.62 \\
0.60- \\
0.64\end{array}$ \\
\hline $\begin{array}{l}\text { Cough } \\
\%(95 \% \text { Cl) }\end{array}$ & $\begin{array}{l}71.08 \\
{[68.36-} \\
73.69]\end{array}$ & $\begin{array}{l}52.68 \\
{[49.51-} \\
55.83]\end{array}$ & $\begin{array}{l}63.55 \\
{[61.79-} \\
65.28]\end{array}$ & $\begin{array}{l}61.08 \\
{[58.48-} \\
63.62]\end{array}$ & $\begin{array}{l}1.50 \\
{[1.39-1.62]}\end{array}$ & $\begin{array}{l}0.55 \\
{[0.49-} \\
0.61]\end{array}$ & $\begin{array}{l}62.56 \\
{[60.47-} \\
64.62]\end{array}$ & $\begin{array}{l}< \\
0.001\end{array}$ & $\begin{array}{l}0.61 \\
0.59- \\
0.63\end{array}$ \\
\hline $\begin{array}{l}\text { Odynophagia } \\
\%(95 \% \text { Cl) }\end{array}$ & $\begin{array}{l}50.00 \\
{[47.07-} \\
52.93]\end{array}$ & $\begin{array}{l}51.06 \\
{[47.9-54.22]}\end{array}$ & $\begin{array}{l}54.25 \\
{[52.11-} \\
56.38]\end{array}$ & $\begin{array}{l}46.80 \\
{[44.72-48.9]}\end{array}$ & $\begin{array}{l}1.02 \\
{[0.94-1.11]}\end{array}$ & $\begin{array}{l}0.98 \\
{[0.90-} \\
1.07]\end{array}$ & $\begin{array}{l}50.46 \\
{[48.35-} \\
52.63]\end{array}$ & 0.62 & $\begin{array}{l}0.5 \\
0.48- \\
0.52\end{array}$ \\
\hline $\begin{array}{l}\text { Thoracic pain } \\
\%(95 \% \text { Cl) }\end{array}$ & $\begin{array}{l}38.76 \\
{[35.93-} \\
41.65]\end{array}$ & $\begin{array}{l}73.41 \\
{[70.54-} \\
76.14]\end{array}$ & $\begin{array}{l}62.85 \\
{[59.85-} \\
65.76]\end{array}$ & $\begin{array}{l}50.80 \\
{[49.32-} \\
52.29]\end{array}$ & $\begin{array}{l}1.46 \\
{[1.28-1.65]}\end{array}$ & $\begin{array}{l}0.83 \\
{[0.79-} \\
0.89]\end{array}$ & $\begin{array}{l}54.8 \\
{[52.66-} \\
56.92]\end{array}$ & $\begin{array}{l}< \\
0.001\end{array}$ & $\begin{array}{l}0.56 \\
0.54- \\
0.58\end{array}$ \\
\hline $\begin{array}{l}\text { Asthenia } \\
\%(95 \% \text { Cl) }\end{array}$ & $\begin{array}{l}68.73 \\
{[65.96-} \\
71.40]\end{array}$ & $\begin{array}{l}42.87 \\
{[39.76-} \\
46.02]\end{array}$ & $\begin{array}{l}58.27 \\
{[56.64-} \\
59.88]\end{array}$ & $\begin{array}{l}54.15 \\
{[51.36-} \\
56.91]\end{array}$ & $\begin{array}{l}1.20 \\
{[1.13-1.29]}\end{array}$ & $\begin{array}{l}0.73 \\
{[0.65-} \\
0.82]\end{array}$ & $\begin{array}{l}56.76 \\
{[54.63-} \\
58.88]\end{array}$ & $\begin{array}{l}< \\
0.001\end{array}$ & $\begin{array}{l}0.55 \\
0.53- \\
0.57\end{array}$ \\
\hline $\begin{array}{l}\text { Myalgia } \\
\%(95 \% \text { Cl) }\end{array}$ & $\begin{array}{l}61.41 \\
{[58.53-} \\
64.24]\end{array}$ & $\begin{array}{l}51.16 \\
{[48.00-} \\
54.32]\end{array}$ & $\begin{array}{l}59.34 \\
{[57.43-} \\
61.22]\end{array}$ & $\begin{array}{l}53.32 \\
{[50.95-} \\
55.68]\end{array}$ & $\begin{array}{l}1.26 \\
{[1.16-1.36]}\end{array}$ & $\begin{array}{l}0.75 \\
{[0.69-} \\
0.83]\end{array}$ & $\begin{array}{l}56.67 \\
{[54.54-} \\
58.78]\end{array}$ & $\begin{array}{l}< \\
0.001\end{array}$ & $\begin{array}{l}0.56 \\
0.54- \\
0.58\end{array}$ \\
\hline $\begin{array}{l}\text { Headache } \\
\%(95 \% \text { Cl) }\end{array}$ & $\begin{array}{l}61.76 \\
{[58.88-} \\
64.58]\end{array}$ & $\begin{array}{l}41.56 \\
{[38.46-} \\
44.70]\end{array}$ & $\begin{array}{l}55.09 \\
{[53.36-} \\
56.08]\end{array}$ & $\begin{array}{l}48.35 \\
{[45.76-} \\
50.96]\end{array}$ & $\begin{array}{l}1.06 \\
{[0.99-1.13]}\end{array}$ & $\begin{array}{l}0.92 \\
{[0.83-} \\
1.02]\end{array}$ & $\begin{array}{l}52.41 \\
{[50.27-} \\
54.55]\end{array}$ & 0.11 & $\begin{array}{l}0.51 \\
0.49- \\
0.53\end{array}$ \\
\hline $\begin{array}{l}\text { Rhinorrhea } \\
\%(95 \% \text { Cl) }\end{array}$ & $\begin{array}{l}32.49 \\
{[29.79-} \\
35.29]\end{array}$ & $\begin{array}{l}71.79 \\
{[68.87-} \\
74.58]\end{array}$ & $\begin{array}{l}57.21 \\
{[54.01-} \\
60.35]\end{array}$ & $\begin{array}{l}47.81 \\
{[46.42-} \\
49.21]\end{array}$ & $\begin{array}{l}1.15 \\
{[1.01-1.31]}\end{array}$ & $\begin{array}{l}0.94 \\
{[0.89-} \\
0.99]\end{array}$ & $\begin{array}{l}50.68 \\
{[48.54-} \\
52.82]\end{array}$ & 0.03 & $\begin{array}{l}0.52 \\
0.50- \\
0.54\end{array}$ \\
\hline $\begin{array}{l}\text { Anosmia } \\
\%(95 \% \text { Cl) }\end{array}$ & $\begin{array}{l}26.92 \\
{[24.37-} \\
29.58]\end{array}$ & $\begin{array}{l}89.79 \\
{[87.73-} \\
91.60]\end{array}$ & $\begin{array}{l}75.37 \\
{[71.31-} \\
79.02]\end{array}$ & $\begin{array}{l}51.42 \\
{[50.40-} \\
52.44]\end{array}$ & $\begin{array}{l}2.64 \\
{[2.14-3.24]}\end{array}$ & $\begin{array}{l}0.81 \\
{[0.78-} \\
0.85]\end{array}$ & $\begin{array}{l}56.01 \\
{[53.88-} \\
58.13]\end{array}$ & $\begin{array}{l}< \\
0.001\end{array}$ & $\begin{array}{l}0.58 \\
0.56- \\
0.59\end{array}$ \\
\hline $\begin{array}{l}\text { Conjunctivitis } \\
\%(95 \% \mathrm{Cl})\end{array}$ & $\begin{array}{l}14.11 \\
{[12.15-} \\
16.26]\end{array}$ & $\begin{array}{l}85.64 \\
{[83.3-87.77]}\end{array}$ & $\begin{array}{l}53.29 \\
{[48.08-} \\
58.43]\end{array}$ & $\begin{array}{l}46.21 \\
{[45.35-} \\
47.07]\end{array}$ & $\begin{array}{l}0.98 \\
{[0.80-1.21]}\end{array}$ & $\begin{array}{l}1.00 \\
{[0.97-} \\
1.04]\end{array}$ & $\begin{array}{l}47.22 \\
{[45.08-} \\
49.36]\end{array}$ & 0.87 & $\begin{array}{l}0.49 \\
0.48- \\
0.51\end{array}$ \\
\hline $\begin{array}{l}\text { Dyspnea } \\
\%(95 \% \text { Cl) }\end{array}$ & $\begin{array}{l}47.91 \\
{[44.98-} \\
50.84]\end{array}$ & $\begin{array}{l}75.94 \\
{[73.15-} \\
78.57]\end{array}$ & $\begin{array}{l}69.80 \\
{[67.07-} \\
72.39]\end{array}$ & $\begin{array}{l}55.67 \\
{[54.05-} \\
57.28]\end{array}$ & $\begin{array}{l}1.99 \\
{[1.76-2.26]}\end{array}$ & $\begin{array}{l}0.69 \\
{[0.64-} \\
0.73]\end{array}$ & $\begin{array}{l}60.88 \\
{[58.77-} \\
62.96]\end{array}$ & $\begin{array}{l}< \\
0.001\end{array}$ & $\begin{array}{l}0.61 \\
0.59- \\
0.63\end{array}$ \\
\hline $\mathrm{O}_{2} \mathrm{~S}<93 \%(95 \% \mathrm{Cl})$ & $\begin{array}{l}11.06 \\
{[9.31-13.02]}\end{array}$ & $\begin{array}{l}95.65 \\
{[94.19-} \\
96.84]\end{array}$ & $\begin{array}{l}74.71 \\
{[67.87-} \\
80.51]\end{array}$ & $\begin{array}{l}48.09 \\
{[47.49-} \\
48.70]\end{array}$ & $\begin{array}{l}2.54 \\
{[1.82-3.56]}\end{array}$ & $\begin{array}{l}0.93 \\
{[0.91-} \\
0.95]\end{array}$ & $\begin{array}{l}50.21 \\
{[48.07-} \\
52.35]\end{array}$ & $\begin{array}{l}< \\
0.001\end{array}$ & $\begin{array}{l}0.53 \\
0.52- \\
0.54\end{array}$ \\
\hline \multicolumn{10}{|l|}{ Combination of symptoms } \\
\hline $\begin{array}{l}\text { Fever and anosmia } \\
\%(95 \% \mathrm{Cl})\end{array}$ & $\begin{array}{l}16.38 \\
{[14.28-} \\
18.65]\end{array}$ & $\begin{array}{l}95.65 \\
{[94.19-} \\
96.84]\end{array}$ & $\begin{array}{l}81.39 \\
{[76.04-} \\
85.76]\end{array}$ & $\begin{array}{l}49.63 \\
{[48.91-} \\
50.35]\end{array}$ & $\begin{array}{l}3.77 \\
{[2.73-5.19]}\end{array}$ & $\begin{array}{l}0.87 \\
{[0.85-} \\
0.90]\end{array}$ & $\begin{array}{l}53.07 \\
{[50.92-} \\
55.20]\end{array}$ & $\begin{array}{l}< \\
0.001\end{array}$ & $\begin{array}{l}0.56 \\
0.54- \\
0.57\end{array}$ \\
\hline $\begin{array}{l}\text { Cough and fever, } \\
\%(95 \% \mathrm{Cl})\end{array}$ & $\begin{array}{l}44.86 \\
{[41.96-} \\
47.79]\end{array}$ & $\begin{array}{l}84.53 \\
{[82.12-} \\
86.73]\end{array}$ & $\begin{array}{l}77.10 \\
{[74.16-} \\
79.78]\end{array}$ & $\begin{array}{l}56.91 \\
{[55.47-} \\
58.34]\end{array}$ & $\begin{array}{l}2.89 \\
{[2.47-3.40]}\end{array}$ & $\begin{array}{l}0.65 \\
{[0.62-} \\
0.69]\end{array}$ & $\begin{array}{l}63.22 \\
{[61.13-} \\
65.27]\end{array}$ & $\begin{array}{l}< \\
0.001\end{array}$ & $\begin{array}{l}0.64 \\
0.62- \\
0.66\end{array}$ \\
\hline $\begin{array}{l}\text { Cough and anosmia } \\
\%(95 \% \mathrm{Cl})\end{array}$ & $\begin{array}{l}21.34 \\
{[19.00-} \\
23.83]\end{array}$ & $\begin{array}{l}92.72 \\
{[90.92-} \\
94.26]\end{array}$ & $\begin{array}{l}77.29 \\
{[72.63-} \\
81.35]\end{array}$ & $\begin{array}{l}50.38 \\
{[48.51-} \\
51.26]\end{array}$ & $\begin{array}{l}2.93 \\
{[2.29-3.76]}\end{array}$ & $\begin{array}{l}0.85 \\
{[0.82-} \\
0.88]\end{array}$ & $\begin{array}{l}54.38 \\
{[52.24-} \\
56.50]\end{array}$ & $\begin{array}{l}< \\
0.001\end{array}$ & $\begin{array}{l}0.57 \\
0.55- \\
0.58\end{array}$ \\
\hline $\begin{array}{l}\text { Fever and dyspnea, } \\
\%(95 \% \text { CI) }\end{array}$ & $\begin{array}{l}33.54 \\
{[30.81-} \\
33.35]\end{array}$ & $\begin{array}{l}88.07 \\
{[85.88-} \\
90.02]\end{array}$ & $\begin{array}{l}76.54 \\
{[73.00-} \\
79.75]\end{array}$ & $\begin{array}{l}53.30 \\
{[52.13-} \\
54.47]\end{array}$ & $\begin{array}{l}2.81 \\
{[2.33-3.39]}\end{array}$ & $\begin{array}{l}0.75 \\
{[0.72-} \\
0.79]\end{array}$ & $\begin{array}{l}58.77 \\
{[56.65-} \\
60.87]\end{array}$ & $\begin{array}{l}< \\
0.001\end{array}$ & $\begin{array}{l}0.60 \\
0.59- \\
0.62\end{array}$ \\
\hline $\begin{array}{l}\text { Anosmia and dyspnea, } \\
\%(95 \% \text { Cl) }\end{array}$ & $\begin{array}{l}13.50 \\
{[11.58-} \\
15.62]\end{array}$ & $\begin{array}{l}95.65 \\
{[94.19-} \\
96.84]\end{array}$ & $\begin{array}{l}78.28 \\
{[72.22-} \\
83.33]\end{array}$ & $\begin{array}{l}48.79 \\
{[48.13-} \\
49.45]\end{array}$ & $\begin{array}{l}3.11 \\
{[2.24-4.31]}\end{array}$ & $\begin{array}{l}0.90 \\
{[0.88-} \\
0.93]\end{array}$ & $\begin{array}{l}51.52 \\
{[49.38-} \\
53.66]\end{array}$ & $\begin{array}{l}< \\
0.001\end{array}$ & $\begin{array}{l}0.54 \\
0.53- \\
0.55\end{array}$ \\
\hline $\begin{array}{l}\text { Fever, cough, anosmia, dyspnea, } \\
\mathrm{O}_{2} \mathrm{~S}<93 \\
\% \text { (95\% Cl) }\end{array}$ & $\begin{array}{l}1.22 \\
{[0.67-2.04]}\end{array}$ & $\begin{array}{l}99.90 \\
{[94.44-100]}\end{array}$ & $\begin{array}{l}93.33 \\
{[64.84-} \\
99.07]\end{array}$ & $\begin{array}{l}46.56 \\
{[46.39-} \\
46.73]\end{array}$ & $\begin{array}{l}12.06 \\
{[1.59-} \\
91.56]\end{array}$ & $\begin{array}{l}0.99 \\
{[0.98-1]}\end{array}$ & $\begin{array}{l}46.89 \\
{[44.75-} \\
49.03]\end{array}$ & 0.002 & $\begin{array}{l}0.50 \\
0.50- \\
0.50\end{array}$ \\
\hline
\end{tabular}


Table 4 Diagnostic accuracy of the diagnostic symptoms scale*

\begin{tabular}{|c|c|c|c|c|c|c|c|c|c|}
\hline $\begin{array}{l}\text { Numbers of } \\
\text { symptoms }\end{array}$ & $\begin{array}{l}\text { Sensitivity } \\
\%\end{array}$ & $\begin{array}{l}\text { Specificity } \\
\%\end{array}$ & PPV \% & NPV \% & LR+ & LR- & Accuracy & $P^{a}$ & AUC \\
\hline $\begin{array}{l}\geq 2 \text { symptoms } \\
{[95 \% \mathrm{Cl}]}\end{array}$ & $\begin{array}{l}83.45 \\
{[81.17-85.55]}\end{array}$ & $\begin{array}{l}32.86 \\
{[29.94-35.89]}\end{array}$ & $\begin{array}{l}59.06 \\
{[57.83-60.28]}\end{array}$ & $\begin{array}{l}63.11 \\
{[59.37-66.69]}\end{array}$ & $\begin{array}{l}1.24 \\
{[1.18-1.31]}\end{array}$ & $\begin{array}{l}0.50 \\
{[0.43-0.59]}\end{array}$ & $\begin{array}{l}60.04 \\
{[57.92-62.2]}\end{array}$ & $<0.001$ & $\begin{array}{l}0.58 \\
{[0.56-0.60]}\end{array}$ \\
\hline $\begin{array}{l}\geq 3 \text { symptoms } \\
{[95 \% \mathrm{Cl}]}\end{array}$ & $\begin{array}{l}67.39 \\
{[64.59-70.10]}\end{array}$ & $\begin{array}{l}58.24 \\
{[55.10-61.34]}\end{array}$ & $\begin{array}{l}65.18 \\
{[63.25-67.06]}\end{array}$ & $\begin{array}{l}60.63 \\
{[58.26-62.96]}\end{array}$ & $\begin{array}{l}1.61 \\
{[1.48-1.76]}\end{array}$ & $\begin{array}{l}0.56 \\
{[0.51-0.62]}\end{array}$ & $\begin{array}{l}63.16 \\
{[61.07-65.21]}\end{array}$ & $<0.001$ & $\begin{array}{l}0.62 \\
{[0.60-0.64]}\end{array}$ \\
\hline $\begin{array}{l}\geq 4 \text { symptoms } \\
{[95 \% \mathrm{Cl}]}\end{array}$ & $\begin{array}{l}49.69 \\
{[46.76-52.63]}\end{array}$ & $\begin{array}{l}80.08 \\
{[77.45-82.53]}\end{array}$ & $\begin{array}{l}76.32 \\
{[71.60-76.86]}\end{array}$ & $\begin{array}{l}57.85 \\
{[56.25-59.44]}\end{array}$ & $\begin{array}{l}2.49 \\
{[2.17-2.86]}\end{array}$ & $\begin{array}{l}0.63 \\
{[0.59-0.67]}\end{array}$ & $\begin{array}{l}63.76 \\
{[61.68-65.81]}\end{array}$ & $<0.001$ & $\begin{array}{l}0.64 \\
{[0.62-0.66]}\end{array}$ \\
\hline $\begin{array}{l}\geq 5 \text { symptoms } \\
\%(95 \% \mathrm{Cl})\end{array}$ & $\begin{array}{l}27.99 \\
{[25.4-30.68]}\end{array}$ & $\begin{array}{l}93.23 \\
{[91.48-94.71]}\end{array}$ & $\begin{array}{l}82.73 \\
{[78.88-86.01]}\end{array}$ & $\begin{array}{l}52.75 \\
{[51.75-53.74]}\end{array}$ & $4.13[3.22-5.30]$ & $\begin{array}{l}0.77 \\
{[0.74-0.80]}\end{array}$ & $\begin{array}{l}58.19 \\
{[56.07-60.30]}\end{array}$ & $<0.001$ & $\begin{array}{l}0.60 \\
{[0.58-0.62]}\end{array}$ \\
\hline $\begin{array}{l}\geq 6 \text { symptoms } \\
\%(95 \% \mathrm{Cl})\end{array}$ & $\begin{array}{l}11.16 \\
{[9.40-13.13]}\end{array}$ & $\begin{array}{l}97.67 \\
{[96.53-98.52]}\end{array}$ & $\begin{array}{l}84.77 \\
{[78.26-89.59]}\end{array}$ & $\begin{array}{l}48.66 \\
{[48.10-49.23]}\end{array}$ & $\begin{array}{l}4.8 \\
{[3.10-7.42]}\end{array}$ & $\begin{array}{l}0.91 \\
{[0.89-0.93]}\end{array}$ & $\begin{array}{l}51.22 \\
{[49.07-53.36]}\end{array}$ & $<0.001$ & $\begin{array}{l}0.54 \\
{[0.52-0.56]}\end{array}$ \\
\hline
\end{tabular}

Abbreviations: PPV positive predictive value, NPV negative predictive value, $L R+$ positive likelihood ratio, $L R$ - negative likelihood ratio, $O R$ odds ratio, $95 \%$ CI $95 \%$ confidence interval

* Symptoms scale that included Fever, cough, anosmia, dyspnea and oxygen saturation < $93 \%$, and headache

${ }^{a} P$ Value estimated with Pearson's $X^{2}$ test

genetic similarity that these viruses have with SARSCoV-2 (89.1\% similarity with SARS-CoV) [25, 26]. Stemming from the above-mentioned, three routes of SARS-CoV-2 invading the nervous system have been proposed: 1) the hematogenous route, 2) the direct route (through the cribriform plate via the olfactory neuro epithelium) and 3) a retrograde axonal transport to the central nervous system [1, 27, 28]. On the other hand, it has been hypothesized that the increase of bradykinins (secondary to SARS-CoV2 infection), specifically DABK, activates the BK1 receptors of the centers in charge of the sense of taste and smell located in the medulla oblongata, which results in the alteration of these senses $[29,30]$.

The strengths of this study include its contribution to the world's information around the prevalence of the symptomatology in patients with COVID-19, studied in a significant amount of symptomatic patients, which allows for the findings and inferences to be relevant; its prospective nature improving its internal validity.

Some of our limitations were: the use of RT-PCR as a reference test, since its diagnostic performance has not been accurately determined [31] and its inherent technical limitations [32]. Some authors have reported a low sensitivity, such as Wang et al. who obtained a sensitivity of $60 \%$ for the detection of SARS-CoV-2 in nasopharyngeal exudate samples [5]. Another limitation was not including gastrointestinal symptoms and taste alterations, which have been reported in other studies [20,33]. More prospective studies regarding the symptomatology associated to COVID-19, that weigh in the symptomatology strategy in the diagnosis of the disease, are required; and finally, the non-inclusion of the 880 patients who did not undergo the SARS-CoV-2 RT-PCR.

\section{Conclusion}

The combination of $\geq 2$ symptoms / signs (fever, cough, anosmia, dyspnea and oxygen saturation $<93 \%$, and headache) results in a highly sensitivity model for a quick and accurate diagnosis of COVID-19, and should be used in the absence of ancillary diagnostic studies. Symptomatology, alone and in combination, may be an appropriate strategy to use in the emergency department to guide the behaviors to respond to the disease.

Table 5 Stratified and multivariate analysis of diagnostic symptoms scale*

\begin{tabular}{|c|c|c|c|c|c|c|}
\hline \multirow[b]{2}{*}{ Numbers of symptoms } & \multicolumn{3}{|c|}{ Stratified analysis } & \multicolumn{3}{|c|}{ Multivariate analysis ${ }^{\mathbf{b}}$} \\
\hline & OR & $95 \% \mathrm{Cl}$ & $P^{a}$ & OR & $95 \% \mathrm{Cl}$ & $P^{a}$ \\
\hline$\geq 2$ symptoms & 2.46 & $2.00-3.04$ & $<0.001$ & 1.28 & $0.98-1.67$ & 0.06 \\
\hline$\geq 3$ symptoms & 2.88 & $2.40-3.45$ & $<0.001$ & 1.23 & $0.93-1.62$ & 0.13 \\
\hline$\geq 4$ symptoms & 3.97 & $3.25-4.84$ & $<0.001$ & 2.01 & $1.15-2.69$ & $<0.001$ \\
\hline$\geq 5$ symptoms & 5.34 & $4.02-7.17$ & $<0.001$ & 2.16 & $1.45-3.20$ & $<0.001$ \\
\hline$\geq 6$ symptoms & 5.27 & $3.32-8.68$ & $<0.001$ & 1.22 & $0.70-2.14$ & 0.46 \\
\hline
\end{tabular}

Abbreviations: OR odds ratio, 95\% Cl 95\% confidence interval

* Symptoms scale that included Fever, cough, anosmia, dyspnea and oxygen saturation $<93 \%$ and headache

${ }^{\text {a }} P$ Value estimated with Pearson's $X^{2}$ test

${ }^{\mathrm{b}}$ Multivariate analysis adjusted by age and gender 


\section{Abbreviations}

WHO: World Health Organization; COVID-19: Coronavirus disease 19; SARSCoV-2: severe acute respiratory syndrome coronavirus 2; LR + : positive likelihood ratio; LR-: negative likelihood ratio; AUC: area under the curve; IQR: interquartile range; SD: standard deviation; OR: odds ratio; 95\% Cl: 95\% confidence interval; SO2 <93\%: saturation of less than 93\%; PPV: positive predictive value; NPV: negative predictive value

\section{Acknowledgements}

The authors have no additional acknowledgments.

\section{Authors' contributions}

CRG contributed in the data collection, statistical analysis and manuscript 's writing; TCM developed the idea for the study; SWH in the data collection and interpretation of data; GVO, EFO, JGP, MIA, MLM, CCG, VMZ, JMO contributed in the data collection; and BGV contributed in statistical analysis, data interpretation and manuscript 's writing. All authors read and approved the final manuscript.

\section{Funding}

The present study was carried out with resources from the Mexican Institute of Social Security.

\section{Availability of data and materials}

The datasets used and/or analyzed during the current study are available from the corresponding author on reasonable request.

Authors have gained informed consent for publication of the dataset from participants at the point of recruitment to the trial.

\section{Declarations}

\section{Ethics approval and consent to participate}

This study protocol was consistent with the ethical guidelines of the 1975 Declaration of Helsinki and the Mexican General Health Law on Research for Health. The written informed consent was obtained from all the patients before the study started and the study was approved by: Institutional registration R-2020-3601-145, Federal Commission for the Protection against Sanitary Risks 17 Cl-09-015-034, National Bioethics Commission: 09 CEI-0232017082.

\section{Consent for publication}

Consent for publication has been obtained from related individual persons whose data were included in the manuscript.

\section{Competing interests}

The authors declare that they have no competing interests.

\section{Author details}

'Otorhinolaryngology Service, Hospital de Especialidades, Centro Médico Nacional Siglo XXI, Instituto Mexicano del Seguro Social, Mexico City, Mexico. ${ }^{2}$ Emergency Department. Hospital de Especialidades, Centro Médico Nacional Siglo XXI, Instituto Mexicano del Seguro Social, Mexico City, Mexico. ${ }^{3}$ Endocrinology Service, Hospital de Especialidades, Centro Médico Nacional Siglo XXI, Instituto Mexicano del Seguro Social, 330 Cuauhtémoc Avenue, 06720 Mexico City, Mexico. ${ }^{4}$ Education and Research Division. Hospital de Especialidades, Centro Médico Nacional Siglo XXI, Instituto Mexicano del Seguro Social, Mexico City, Mexico. ${ }^{5}$ General Director of the Hospital de Especialidades, Centro Médico Nacional Siglo XXI, Instituto Mexicano del Seguro Social, Mexico City, Mexico.

Received: 5 November 2020 Accepted: 17 February 2021 Published online: 11 March 2021

\section{References}

1. WHO. Epidemiological Update: Coronavirus disease (COVID-19) - 15 October 2020. 2020 Apr 29; Available from: https://www.paho.org/en/documents/ epidemiological-update-coronavirus-disease-covid-19-15-october-2020

2. Secretaria de Salud. Informe Técnico Diario COVID-19 MÉXICO. 2020. Available from: https:/www.gob.mx/cms/uploads/attachment/file/589816/ Comunicado_Tecnico_Diario_COVID-19_2020.11.01.pdf.
3. Grant MC, Geoghegan L, Arbyn M, Mohammed Z, McGuinness L, Clarke EL, et al. The prevalence of symptoms in 24,410 adults infected by the novel coronavirus (SARS-CoV-2; COVID-19): a systematic review and meta-analysis of 148 studies from 9 countries. PLoS One. 2020;15(6):e0234765. https://doi. org/10.1371/journal.pone.0234765.

4. Wölfel R, Corman VM, Guggemos W, Seilmaier M, Zange S, Müller MA, et al. Virological assessment of hospitalized patients with COVID-2019. Nature. 2020;581(7809):465-9. https://doi.org/10.1038/s41586-020-2196-X.

5. Wang W, Xu Y, Gao R, Lu R, Han K, Wu G, et al. Detection of SARS-CoV-2 in different types of clinical specimens. JAMA. 2020;323(18):1843-4. https://doi. org/10.1001/jama.2020.3786.

6. Kovács A, Palásti P, Veréb D, Bozsik B, Palkó A, Kincses ZT. The sensitivity and specificity of chest CT in the diagnosis of COVID-19. Eur Radiol. 2020:16. https://doi.org/10.1007/s00330-020-07347-x.

7. Ayebare RR, Flick R, Okware S, Bodo B, Lamorde M. Adoption of COVID-19 triage strategies for low-income settings. Lancet Respir Med. 2020;8(4):e22. https://doi.org/10.1016/S2213-2600(20)30114-4.

8. Jernigan JA, Low DE, Hefland RF. Combining clinical and epidemiologic features for early recognition of SARS. Emerg Infect Dis. 2004;10(2):327-33. https://doi.org/10.3201/eid1002.030741.

9. Whiteside T, Kane E, Aljohani B, Alsamman M, Pourmand A. Redesigning emergency department operations amidst a viral pandemic. Am J Emerg Med. 2020;38(7):1448-53. https://doi.org/10.1016/j.ajem.2020.04.032.

10. Struyf T, Deeks JJ, Dinnes J, Takwoingi Y, Davenport C, Leeflang MMG, et al. Signs and symptoms to determine if a patient presenting in primary care or hospital outpatient settings has COVID-19 disease. Cochrane Database Syst Rev. 2020;7:CD013665. https://doi.org/10.1002/14651858.CD013665.

11. Secretaría de Salud, Dirección General de Epidemiología. Comunicado Oficial. Com Nac para la Vigil Epidemiológica [Internet]. 2020;1. Available from: https://www.gob.mx/cms/uploads/attachment/file/573732/Comunica do_Oficial_DOC_sospechoso_ERV_240820.pdf

12. Secretaria de salud. Datos Abiertos - Dirección General de Epidemiología. Gobierno de México. 2020. https://www.gob.mx/salud/documentos/datos-a biertos-152127?idiom=es. Accessed July 21.

13. Romero-Gameros CA, Waizel-Haiat S, Mendoza-Zubieta V, Anaya-Dyck A, López-Moreno MA, Colin-Martinez T, et al. Evaluation of predictive value of olfactory dysfunction, as a screening tool for COVID-19. Laryngoscope Investig Otolaryngol. 2020;5:983-991. doi:https://doi.org/10.1002/lio2.482

14. Ortiz-Hernández L, Pérez-Sastré MA. Inequidades sociales en la progresión de la COVID-19 en población mexicana [Social inequalities in the progression of COVID-19 in the Mexican population]. Rev Panam Salud Publica. 2020;44:e106-e106. doi:https://doi.org/10.26633/RPSP.2020.106

15. Peak CM, Childs LM, Grad YH, Buckee CO. Comparing nonpharmaceutical interventions for containing emerging epidemics. Proc Natl Acad Sci. 2017; 114(15):4023-8. https://doi.org/10.1073/pnas.1616438114.

16. Caeiro JP, Garzón Ml. Controlling infectious disease outbreaks in lowincome and middle-income countries. Curr Treat options Infect Dis. 2018; 10(1):55-64. https://doi.org/10.1007/s40506-018-0154-z.

17. Chow EJ, Schwartz NG, Tobolowsky FA, Zacks RLT, Huntington-Frazier M, Reddy SC, et al. Symptom screening at illness onset of health care personnel with SARS-CoV-2 infection in King County. Washington JAMA 2020;323(20):2087-9. https://doi.org/10.1001/jama.2020.6637.

18. Tostmann A, Bradley J, Bousema T, Yiek WK, Holwerda M, Bleeker-Rovers C, et al. Rapid communication Strong associations and moderate predictive value of early symptoms for SARS-CoV-2 test positivity among healthcare workers, the Netherlands, March 2020. Euro Surveill. 2020;25(16):pii= 2000508. doi:https://doi.org/10.2807/1560-7917.ES.2020.25.16.2000508

19. Hopman J, Allegranzi B, Mehtar S. Managing COVID-19 in Low- and middleincome countries. JAMA. 2020;323(16):1549-50. https://doi.org/10.1001/ja ma.2020.4169.

20. Peyrony $\mathrm{O}$, Marbeuf-Gueye C, Truong V, Giroud M, Rivière C, Khenissi K. E al. Accuracy of emergency department clinical findings for diagnosis of coronavirus disease 2019. Ann Emerg Med. 2020;76(4):405-12. https://doi. org/10.1016/j.annemergmed.2020.05.022.

21. Salmon Ceron D, Bartier S, Hautefort C, Nguyen Y, Nevoux J, Hamel AL, et al. Self-reported loss of smell without nasal obstruction to identify COVID-19. The multicenter Coranosmia cohort study. J Inf Secur. 2020;81(4); 614-20. https://doi.org/10.1016/j.jinf.2020.07.005.

22. Lan F-Y, Filler R, Mathew S, Buley J, Iliaki E, Bruno-Murtha LA, et al. COVID-19 symptoms predictive of healthcare workers' SARS-CoV-2 PCR results. PLOS One. 2020;15(6):e0235460. https://doi.org/10.1371/journal.pone.0235460. 
23. Hamming I, Timens W, Bulthuis MLC, Lely AT, Navis GJ, van Goor H. Tissue distribution of ACE2 protein, the functional receptor for SARS coronavirus. A first step in understanding SARS pathogenesis. J Pathol. 2004;203(2):631-7. https://doi.org/10.1002/path.1570

24. Wu Y, Xu X, Chen Z, Duan J, Hashimoto K, Yang L, et al. Nervous system involvement after infection with COVID-19 and other coronaviruses. Brain Behav Immun. 2020;87:18-22. https://doi.org/10.1016/j.bbi.2020.03.031.

25. Zhou Z, Kang H, Li S, Zhao X. Understanding the neurotropic characteristics of SARS-CoV-2: from neurological manifestations of COVID-19 to potential neurotropic mechanisms. J Neurol. 2020;267(8):2179-84. https://doi.org/10.1 007/s00415-020-09929-7.

26. Li Y-C, Bai W-Z, Hashikawa T. The neuroinvasive potential of SARS-CoV2 may play a role in the respiratory failure of COVID-19 patients. J Med Virol. 2020; 92(6):552-5. https://doi.org/10.1002/jmv.25728.

27. Ahmad I, Rathore FA. Neurological manifestations and complications of COVID-19: a literature review. J Clin Neurosci. 2020;77:8-12. https://doi.org/1 0.1016/j.jocn.2020.05.017.

28. Abboud H, Abboud FZ, Kharbouch H, Arkha Y, El Abbadi N, El Ouahabi A. COVID-19 and SARS-Cov-2 infection: pathophysiology and clinical effects on the nervous system. World Neurosurg. 2020;140:49-53. https://doi.org/10.1 016/j.wneu.2020.05.193.

29. Nicolau LAD, Magalhães PJC, Vale ML. What would Sérgio Ferreira say to your physician in this war against COVID-19: how about kallikrein/kinin system? Med Hypotheses. 2020;143:109886. https://doi.org/10.1016/j.mehy.2 020.109886.

30. Fior DR, Martins DT, Lindsey CJ. Localization of central pressor action of bradykinin in medulla oblongata. Am J Physiol Circ Physiol. 1993;265(3): H1000-6. https://doi.org/10.1152/ajpheart.1993.265.3.H1000.

31. Marcotte LM, Liao JM. Incorporating test characteristics into SARS-CoV-2 testing policy—sense and sensitivity. JAMA Heal Forum. 2020;1 (4):e200448. https://doi.org/10.1001/jamahealthforum.2020.0448.

32. Cancella de Abreu M, Choquet C, Petit H, Bouzid D, Damond F, Marot S, et al. SARS-CoV-2 IGM and IGG rapid serologic test for the diagnosis of COVID-19 in the emergency department. J Infect. 2020;501634453(20)30513-2. doi:https://doi.org/10.1016/j.jinf.2020.07.032

33. Tong JY, Wong A, Zhu D, Fastenberg JH, Tham T. The prevalence of olfactory and gustatory dysfunction in COVID-19 patients: a systematic review and meta-analysis. Otolaryngol Neck Surg. 2020;163(1):3-11. https:// doi.org/10.1177/0194599820926473

\section{Publisher's Note}

Springer Nature remains neutral with regard to jurisdictional claims in published maps and institutional affiliations.

Ready to submit your research? Choose BMC and benefit from:

- fast, convenient online submission

- thorough peer review by experienced researchers in your field

- rapid publication on acceptance

- support for research data, including large and complex data types

- gold Open Access which fosters wider collaboration and increased citations

- maximum visibility for your research: over $100 \mathrm{M}$ website views per year

At BMC, research is always in progress.

Learn more biomedcentral.com/submissions 